\title{
Overview of the Black Fungus Gnats from the Tristan da Cunha archipelago, including a redescription of Hyperlasion viridiventris (FREY) (Diptera: Sciaroidea: Sciaridae)
}

With 2 maps, 23 figures and 1 table

Frank Menzel ${ }^{1}$, Pekka VilkamaA ${ }^{2}$ and Jane E. Smith ${ }^{3}$

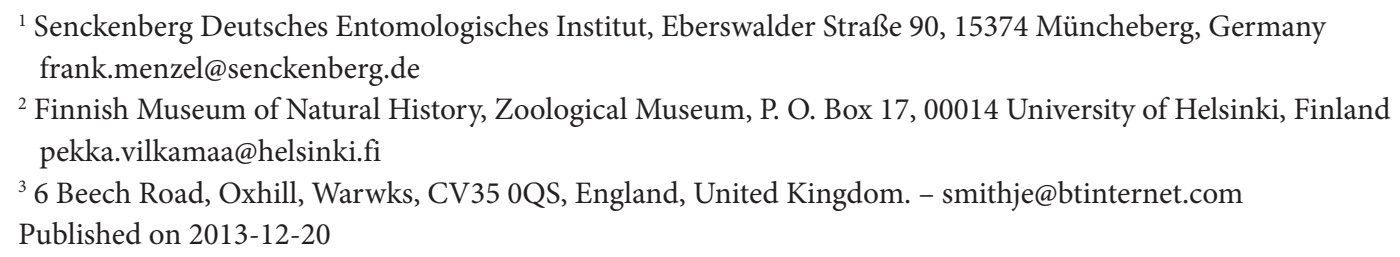

\section{Summary}

Black Fungus Gnats (Diptera: Sciaridae) were collected with Malaise traps on Tristan da Cunha and Nightingale islands in the South Atlantic. Four species were identified of which Lycoriella sativae (JoHAnnsen, 1912) is already known from literature. For three others - Bradysia tilicola (LoEw, 1850), Hyperlasion viridiventris (Frey, 1945) and Pseudolycoriella setigera (HARDY, 1960) - this is the first report from this archipelago. To date, 8 species are known from this group of islands. They belong to the genera Bradysia Winnertz (3 species), Cosmosciara Frey (1), Hyperlasion Schmitz (1), Lycoriella Frey (2) and Pseudolycoriella Menzel \& Mohrig (1). The male genitalia for 7 particularly well known sciarid species from the archipelago are already illustrated but until now only poorly preserved type specimens of Hyperlasion viridiventris (Frey) from the Azores were known. Both male and female have been redescribed from the new material. An overview is also given of the existing sciarid records from the islands. The published data were analysed and compared with the new records.

\section{Key words}

Diptera, Sciaroidea, Sciaridae, Bradysia, Cosmosciara, Hyperlasion, Lycoriella, Pseudolycoriella, Afrotropical Region, South Atlantic, Tristan da Cunha archipelago, overview, distribution, redescription, new records

\section{Zusammenfassung}

Auf den beiden Inseln Tristan da Cunha und Nightingale im Südatlantik wurden mit Malaisefallen Trauermücken (Diptera: Sciaridae) gesammelt. Im Ergebnis dessen konnten 4 Arten nachgewiesen werden, von denen Lycoriella sativae (JohANNSEN, 1912) aus der Literatur schon bekannt war. Drei andere - Bradysia tilicola (Loew, 1850), Hyperlasion viridiventris (FREY, 1945) und Pseudolycoriella setigera (HARDY, 1960) - werden zum ersten Mal von dem Archipel gemeldet. Zur Zeit sind 8 Spezies von der Inselgruppe bekannt. Diese gehören zu den Gattungen Bradysia WinNERTZ (3 Spezies), Cosmosciara Frey (1), Hyperlasion Schmitz (1), Lycoriella Frey (2) und Pseudolycoriella Menzel \& Mohrig (1). Von den 7 namentlich bekannten Trauermücken-Arten des Archipels wurden die männlichen Genitalstrukturen abgebildet. Von Hyperlasion viridiventris (FREY) existierten bisher nur die schlecht erhaltenen Typ- 
exemplare von den Azoren. Auf der Basis des neuen Materials werden die Männchen und Weibchen redeskribiert. Außerdem wird eine Übersicht über die bis heute bekannt gewordenen Sciaridenfunde von der Inselgruppe gegeben. Die publizierten Funddaten wurden analysiert und mit den neuen Nachweisen verglichen.

\section{Stichwörter}

Diptera, Sciaroidea, Sciaridae, Bradysia, Cosmosciara, Hyperlasion, Lycoriella, Pseudolycoriella, afrotropische Region, Südatlantik, Tristan da Cunha-Archipel, Übersicht, Verbreitung, Redeskription, neue Nachweise

\section{Introduction}

The four main islands of the Tristan da Cunha archipelago, Tristan da Cunha, Nightingale, Inaccessible and Gough, all lie in the South Atlantic between $37^{\circ} \mathrm{S} 12^{\circ} \mathrm{W}$ and $40^{\circ} \mathrm{S} 09^{\circ} \mathrm{W}$ [see map and locality description in Hänel \& Heyne (2008): 122, fig. 1].

The Sciaridae, commonly known as Black Fungus Gnats, were first recorded at the archipelago from a collection made in the three northern islands (Inaccessible, Nightingale, Tristan da Cunha) during the 'Norwegian Expedition to Tristan da Cunha in 1937-1938'. This brought to light two species, namely Cosmosciara perniciosa (EdWARds, 1922) and Bradysia mycorum FreY, 1948 [in MENZEL \& MOHRIG (2000) a junior synonym of Lycoriella ingenua (Dufour, 1839)], both regarded as cosmopolitan species (FrEY 1954). Subsequently two more species were recorded from a collection made during the Gough Island Scientific Survey of 1956-1957. They were two undetermined species of Bradysia Winnertz (FreEMAN 1962). One of these was later identified with additional material collected during the 'Gough Island Terrestrial Invertebrate Survey of 1999-2001', as Bradysia nocturna
Tuомıкоsкi, 1960 [= B. forficulata (Bezzi, 1914)] with Holarctic distribution was not mentioned in Jones et al. (2003). Also recorded from the 1999-2001 collection was another genus, namely Lycoriella FrEY, 1942, represented by two species.

To further investigate and update the situation in the northern islands, a brief invertebrate collecting project was carried out at Tristan da Cunha and Nightingale islands in early 2005 as a snippet of a larger program entitled 'Empowering the People of Tristan da Cunha to Implement the Convention on Biological Diversity (CBD)' (HäNEL 2005).

The authors, having pursued the findings beyond the scope of the projects means, here present the information that has come to light from that collection. Involved are four identifiable species, three of which had not been recorded from the archipelago before. These include the rare and poorly known species Pseudolycoriella setigera (HARDY, 1960) and Hyperlasion viridiventris (FREY, 1945). The findings are presented, discussed and summarised together with existing information, so as to provide an overview of the 'status quo' with regards to the Sciaridae as currently known for the Archipelago.

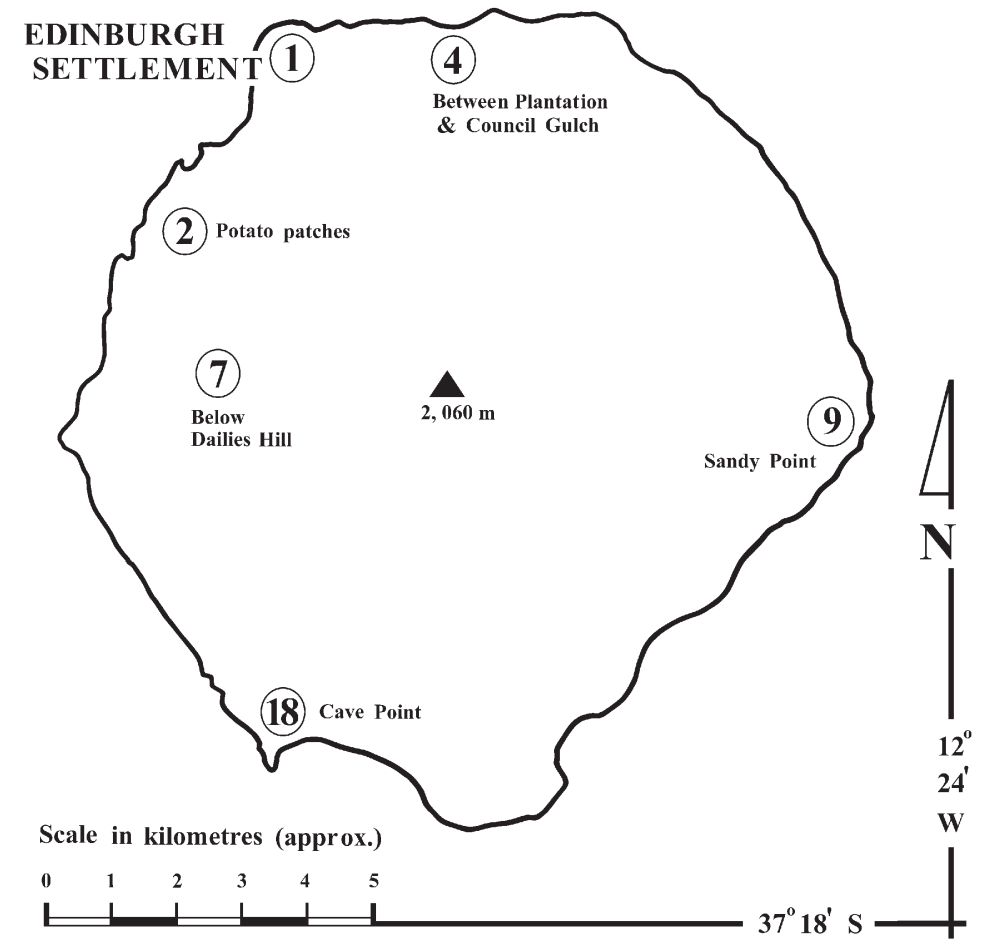

Map 1: Sample sites on Tristan da Cunha Island where sciarids were collected in 2005. Map drawn by C. HÄNEL. 


\section{Material and methods}

The fieldwork was conducted by CHRISTINe HäNeL on Tristan da Cunha and Nightingale Islands (hereafter referred to as 'Tristan' and 'Nightingale') between early February and the beginning of April, 2005. The majority of the time was spent on Tristan and a period of two weeks on Nightingale. Sampling was random and opportunistic, but focused on trying to cover the major habitat types represented. On Tristan, 23 sites at eight different locations were sampled. Most of the areas sampled (62.5\%) were in the lowlands, although a few (12.5\%) were on the slopes above, and a couple (2.5\%) were on the plateau. No higher altitudes were sampled. The habitats encompassed principally agricultural crop and pastures, some 'intruded' fern-bush communities, and a boggy wetland (Soggy Plain). On Nightingale, 10 sites were sampled in two main regions. The latter comprised the lowland areas dominated by tussock grasslands and the higher central wetland areas. Sciaridae were obtained at six of the eight Tristan localities (Map 1) and at both localities on Nightingale (Map 2).

Flies were principally collected using Malaise traps. All specimens were preserved in $70 \%$ ethanol. The specimens were prepared by P. Vilkamaa as permanent mounts for microscopic examination using Euparal as mountant. The nomenclature and systematics used are based on the revisions by Menzel \& Mohrig (2000) and Menzel \& Sмiтн (2009). Representatives of each species from Tristan da Cunha archipelago are deposited in the following collections (HäNEL, pers. comm.):
ANRT $=$ Agriculture and Natural Resources Department, Tristan da Cunha, British overseas territory of Saint Helena, United Kingdom ( $0^{\top} 0^{*}$ and $q+9$ of $H$. viridiventris from Tristan and Nightingale / $\sigma^{\star} o^{t}$ of $P$. setigera from Tristan)

MZH $=$ Zoological Museum of the Finnish Museum of Natural History, Helsinki, Finland (B. tilicola: $1 \sigma^{\top}$ from Tristan) / H. viridiventris: $2 o^{\top} \sigma^{\top}$ from Tristan; $2 o^{\rightarrow} o^{\top} 2$ 우 우 from Nightingale / P. setigera: 1 o from Tristan)

$\mathrm{BMNH}=$ The Natural History Museum, London, Great Britain [formerly British Museum of Natural History] (Bradysia specimens from Gough collected by M. Holdgate, cited by Freeman (1962): p. 79)

SAMC = IZIKO Museums of Cape Town, South African Museum, Cape Town, South Africa (H. viridiventris: 1 ㅇ from Nightingale / P. setigera: $10^{\text {t }}$ from Nightingale)

SDEI = Senckenberg Deutsches Entomologisches Institut, Müncheberg, Germany (H. viridiventris: $1 \sigma^{*}$ 1 ㅇ from Nightingale)
Map 2: Sample sites on Nightingale Islands where sciarids were collected in 2005. Map drawn by C. HäNEL.

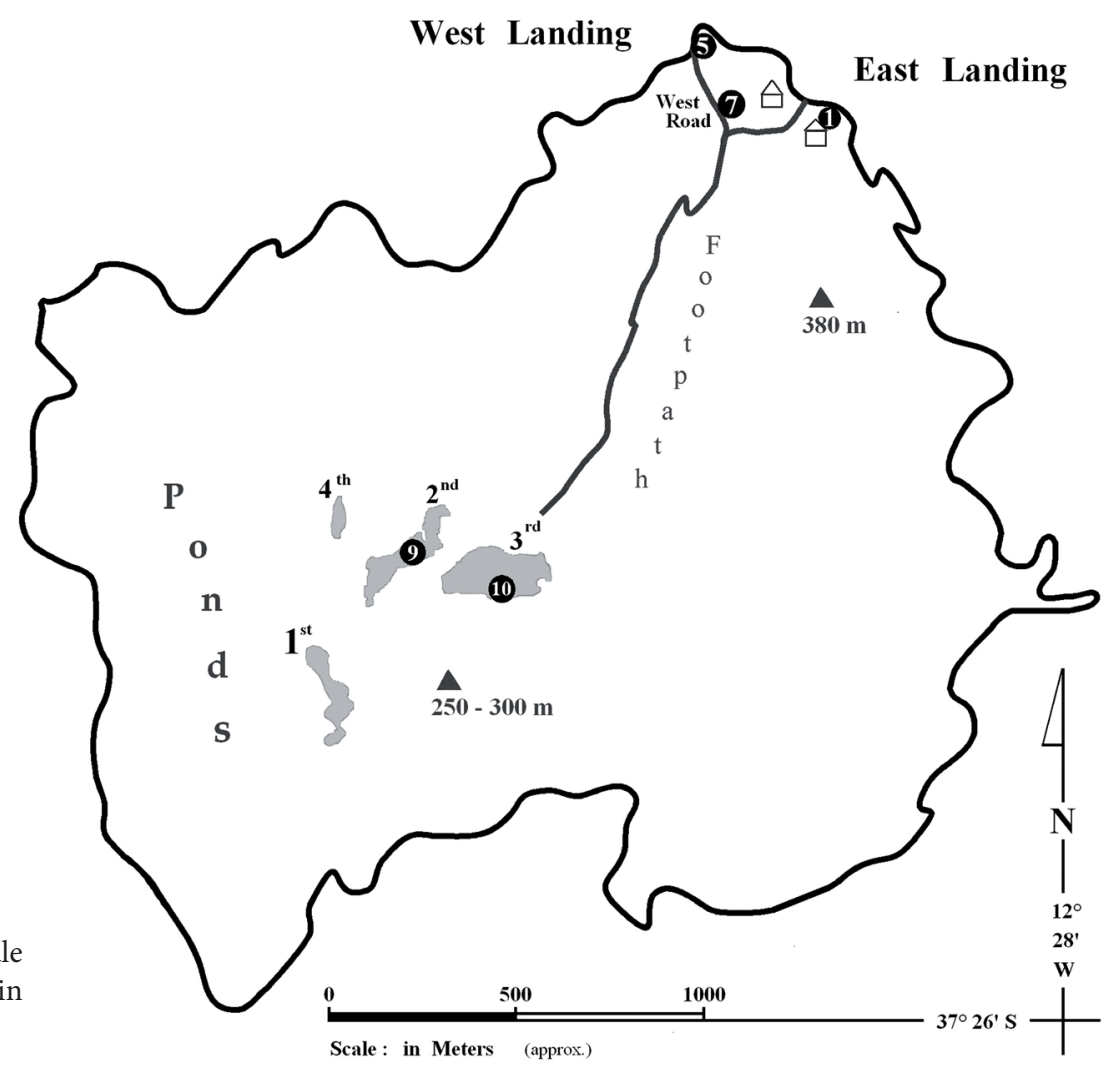




\section{Results}

In total four Sciaridae species were collected in 2005. These are Bradysia tilicola (LoEw, 1850), Hyperlasion viridiventris (FREY, 1945), Lycoriella sativae (JOHANNSEN, 1912), and Pseudolycoriella setigera (HARDY, 1960). The details for the collected specimens are summarised below with the data pertaining to the relevant sites (e.g. locality, habitat, and vegetation types) and a general overview of the species status.

\section{Bradysia forficulata (Bezzı, 1914)}

(Figs 1-3)

\section{Synonyms:}

= Sciara luravi Johannsen, 1929; = Bradysia nocturna Tuомiкoski, 1960.

\section{Selected literature:}

- Tuomikoski (1960): 139 and 141, fig. 32f [as Bradysia nocturna]; - FreEmAN (1962): 79 [as Bradysia sp. 1]; - Holdgate (1965): 383 and 396 [in part as Bradysia sp.]; - Mohrig \& Menzel (1993): 270 and 283, fig. 15d; - Menzel \& Mohrig (2000): 141; - Gaston et al. (2003): 1095; - Jones et al. (2003): 241 and 246, fig. 28b; - Menzel et al. (2006): 53 [all as Bradysia nocturna]; Heller \& Weber (2013): 321, figs 4, 5; - Mohrig et al. (2013): 159, figs 10a, 10b [all as Bradysia forficulata].

Material from the archipelago:

Only known from the literature (FreEMAN 1962, HoldGATE 1965, GASton et al. 2003, Jones et al. 2003).

\section{Distribution:}

Cosmopolitan. Common and widely distributed in Europe (Austria, Bosnia and Herzegovina, Czech Republic, Finland, France, Germany, Great Britain, Greece, Hungary, Ireland, Italy, Luxembourg, the Netherlands, Norway, Poland, Russia [European territory], Spain [mainland], Sweden, Switzerland). Also known from North America (Canada: Alberta, British Columbia / USA: Arizona, California, Georgia, Tennessee, Texas, Virginia). Outside Holarctic region only recorded from Gough Island ( $7 \sigma^{*} \sigma^{*} 2$ 우 9 in the BMNH collection).

Description: See Tuomikoski (1960): 139 and 141, fig. $32 \mathrm{f}$.

\section{Discussion:}

Heller \& Weber (2013) consider Bradysia nocturna TuOMIKoski as junior synonym of Bradysia forficulata (BEzzI, 1914). The genitalia of 'nocturna' and 'forficulata' are in fact identical, only in 'forficulata' the legs and antennae are elongated and the individuals are larger as a result of adaptation to life in caves. Bradysia forficulata is distributed through the whole of Europe and is also pre- sent in North America, including caves (ReEves 2000, ReEves et al. 2000). Additionally, it seems that B. forficulata $[=B$. nocturna $]$ is able to use microcaves such as burrows of moles, shrews, rabbits and other small mammals as well as of wasps. Burrows of the house mouse (Mus musculus), which was introduced on Gough Island in the 19 th century, might serve as an appropriate habitat for Bradysia forficulata (BEZzI).

\section{Bradysia tilicola (LoEW, 1850) \\ (Figs 4, 5)}

\section{Synonyms:}

= Sciara amoena WINNERTZ, 1867; = Sciara caldaria LinTNER, 1895; = Sciara coprophila LINTNER, 1895; = Sciara marcilla Hutton, 1902; = Neosciara sexdentata Pettey, 1918; = Sciara (Neosciara) nanella Frey, 1936 [more synonyms in Menzel \& Mohrig (2000)].

\section{Selected literature:}

- Loew (1850): 18 [as Sciara]; - Winnertz (1867): 114 [as Sciara amoena]; - Lintner (1895): 394, figs 4, 5a-e, plate 1, figs 1-4, 6, 8, 9, 11, 11a [as Sciara coprophila]; - Hutton (1902): 192 [as Sciara marcilla]; - Frey (1936): 15, plate 4, fig. 33 [as Sciara (Neosciara) nanella]; - JohAnNSEN (1912): 120, 123 and 136, plate 3, figs 13, 144, plate 6, fig. 236, plate 7, fig. 259 [as Sciara coprophila]; - ToNNOIR \& EdWARds (1927): 797, plate 70, fig. 185 [as Sciara marcilla]; - STEFFAN (1966): 22 and 35, figs 1, 5 [as Bradysia coprophila]; - FreEMAN (1983): 36, figs 130-132; - Menzel \& Mohrig (2000): 147, figs 132, 133 [all as Bradysia amoena]; - Menzel \& Heller (2005): 351; - Menzel et al. (2006): 63; - Mohrig et al. (2013): 171 [all as Bradysia tilicola].

\section{Material examined from the archipelago:}

TRISTAN DA CUNHA ISLAND: Cave Point, in front of hut, $37^{\circ} 16^{\prime} 77^{\prime \prime S} 12^{\circ} 32^{\prime} 54^{\prime \prime} \mathrm{W}, 71 \mathrm{ft}$. a.s.l., grassland and

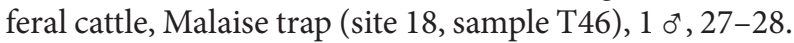
ii.2005, leg. HëNEL (MZH).

\section{Distribution:}

Known from United States (California, Idaho, Kansas, Maine, North Carolina, New York), Azores [Portugal], Canary Islands [Spain], Morocco, Europe (Austria, Belgium, Bulgaria, Czech Republic, Finland, Germany, Great Britain, Greece, Estonia, Ireland, Italy, Lithuania, the Netherlands, Poland, Romania, Russia [European territory], Slovakia, Spain [Iberian Peninsula], Sweden, Turkey (Asian territory), Russia (Asian territory: Altay), Nepal and New Zealand. New to Tristan da Cunha archipelago.

Description: See Menzel \& Mohrig (2000): 147, figs 132, 133 [as Bradysia amoena]. 


\section{Discussion:}

Bradysia tilicola is perhaps the most common species of Sciaridae worldwide. Due to its cosmopolitan distribution it has been described under different names 19 times. For a complete list of synonymies see Menzel \& Mohrig (2000). The species is potentially present in nearly every house in the world with indoor plants. The larvae develop in flowerpots and may occasionally cause damage to the plants. The species is also found outdoors, but is never highly abundant. It may spread out actively from human settlements and is most likely to having been introduced with plants to nearly any place with human activities and also to Tristan da Cunha. There are already records from other archipelagoes like the Azores and the Canary Islands. For more detailed information about habitats see Menzel et al. (2006).

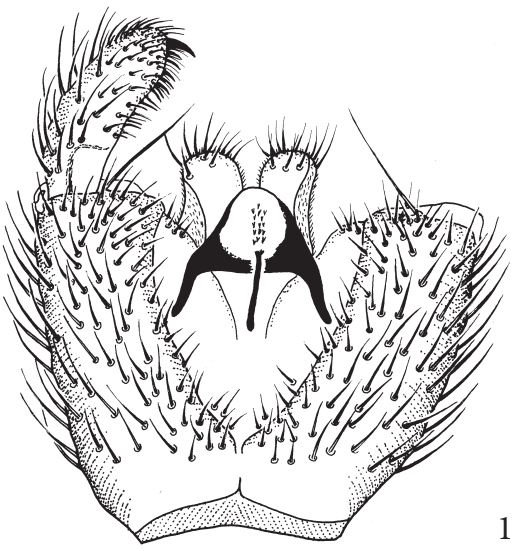

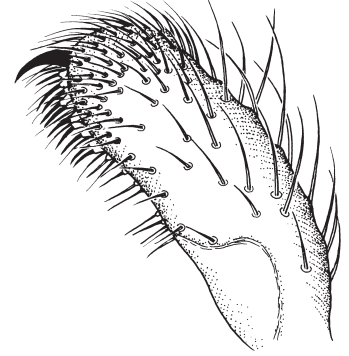

2

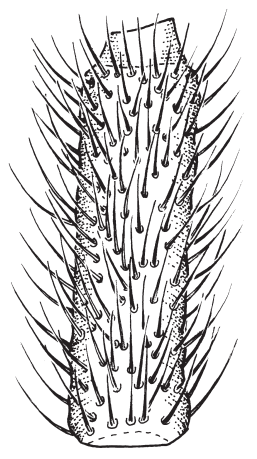

3
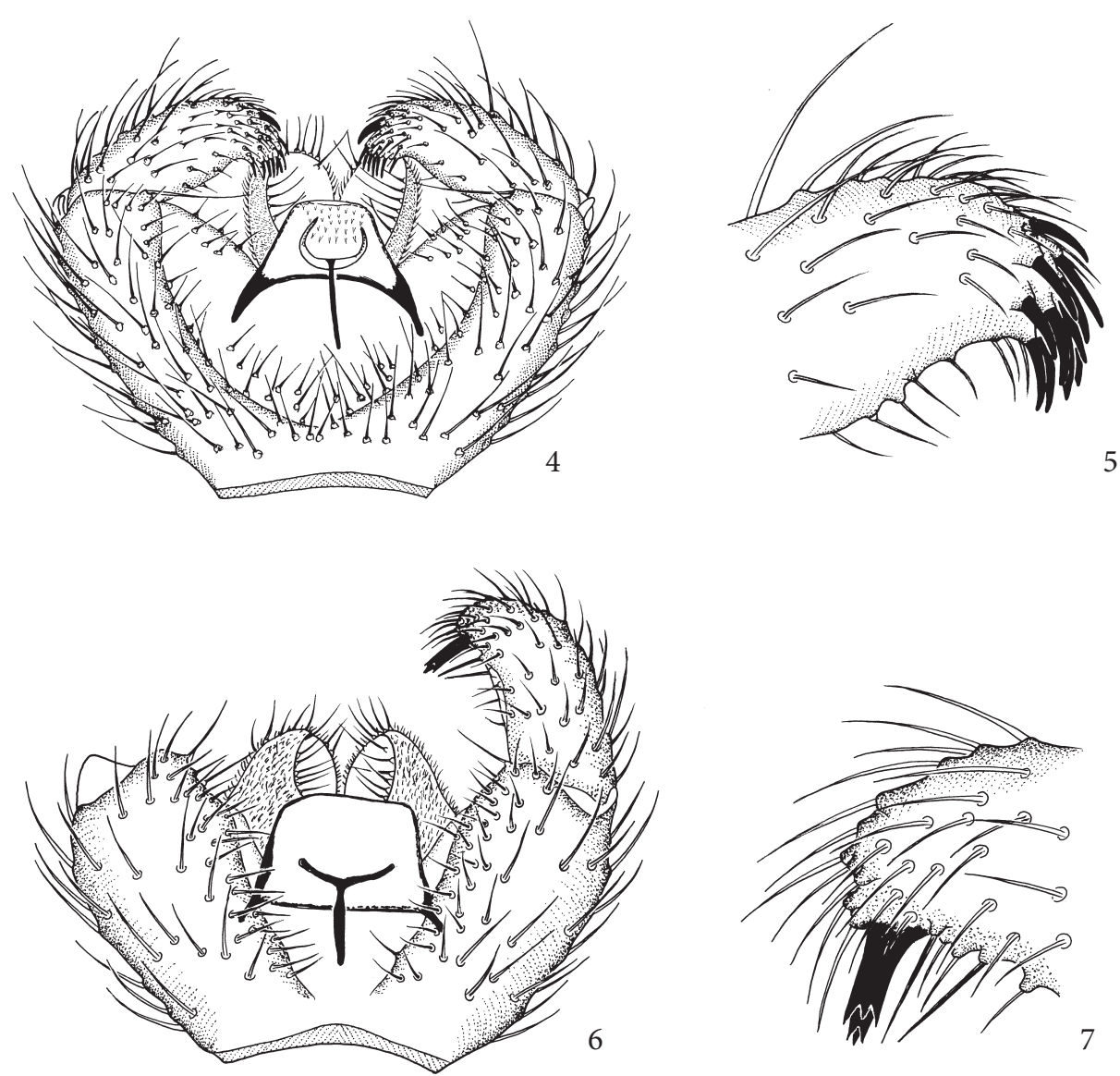

Figs 1-7: Bradysia forficulata (Bezzi), male (Figs 1-3): - Fig. 1: Hypopygium in ventral view; - Fig. 2: Right gonostyle in ventral view; - Fig. 3: 4th flagellomere in lateral view. Bradysia tilicola (Loew), male (Figs 4, 5); - Fig. 4: Hypopygium in ventral view; Fig. 5: Apical part of left gonostyle in ventral view. Cosmosciara perniciosa (EDwARDs), male (Figs 6, 7); - Fig. 6: Hypopygium in ventral view; - Fig. 7: Apical part of right gonostyle in ventral view. 


\section{Bradysia sp. 2}

\section{Literature:}

- Freeman (1962): 79 [as Bradysia sp. 2]; - Holdgate (1965): 383, 384 and 396 [in part as Bradysia sp.]; - Jones et al. (2003): 246 [in part as B. nocturna Tuomiкoski].

Material from the archipelago:

Only known from the literature (FREEMAN 1962, HoLDGATE 1965).

\section{Distribution:}

Recorded from Gough Island $(2$ ㅇ 9 in the $\mathrm{BMNH}$ collection).

\section{Discussion:}

Under the name 'Bradysia sp. 2' FreEmAN (1962: 79) listed two females collected by M. Holdgate. We have studied this material. Both females are possibly conspecific with 'Bradysia sp. 1', that P. VilkamaA identified in Jones et al. (2003) as Bradysia nocturna Tuomikoski [= Bradysia forficulata (BEzzI, 1914)].

\section{Cosmosciara perniciosa (EdwARDS, 1922)}

(Figs 6, 7)

\section{Synonyms:}

= Plastosciara (Cosmosciara) brevicalcarata HARDY, 1956;

= Epidapus (Epidapus) semifactus MoHrig \& RöscHMANN, 1999.

\section{Selected literature:}

- Edwards (1922): 160 [as Plastosciara]; - Frey (1954): 2, 3 and 11 [as Cosmosciara]; - HARdy (1956): 73, fig. 2a-e [as Plastosciara brevicalcarata]; - HARDY (1960): 215 [as Plastosciara (Cosmosciara)]; - Holdgate (1965): 396 [as Cosmosciara]; - Steffan (1973a): 360 [as Plastosciara (Termitosciara)]; - StefFAN (1973b): 1265, figs 1, 2; - Steffan (1974): 48 [all as Plastosciara]; - Freeman (1983): 25, figs 49, 60 [as Plastosciara (Termitosciara)]; - Rulik et al. (1999): 31, fig. 7a-e [as Epidapus semifactus]; - Menzel \& Mohrig (2000): 288; - Menzel et al. (2006): 87 [all as Cratyna (Peyerimhoffia)]; - MenzeL \& Heller (2007): 217; - Menzel \& Smith (2009): 32, figs 1.21-1.25 [all as Cosmosciara].

Material from the archipelago:

Only known from the literature (FrEY 1954).

\section{Distribution:}

Cosmopolitan. Recorded by Frey (1954) from Inaccessible, Nightingale and Tristan da Cunha (only females). Also known from Ecuador (Galapagos Islands), Costa Rica, United States (Hawaiian Islands), French Polynesia (Marquesas Islands: Eiao, Tahuata), Philippines (Palawan), China, Seychelles Islands (Silhouette), United
Arab Emirates, Iraq, Canary Islands [Spain], and Europe (Czech Republic, Finland, Germany, Great Britain, Greece, the Netherlands, Russia [European territory]).

Description: See Menzel \& SMith (2009): 32, figs 1.211.25 .

\section{Discussion:}

Cosmosciara perniciosa has only occasionally been recorded in Europe from natural habitats like moor, dry grassland and deciduous woodland, but was mostly found near human settlements, in gardens and glasshouses, even as a pest on young plants (e.g. cucumbers). As the genus Cosmosciara is more tropical than Palaearctic, it can be assumed that this species was introduced into Europe by man. In that way it has most probably reached many distant islands, also the Tristan da Cunha archipelago.

\section{Hyperlasion viridiventris (FREY, 1945)}

(Figs 8-17)

\section{Literature:}

- Frey (1945): 17, plate 2, figs 16-18 [as Scythropochroa (Hyperlasion)]; - Menzel \& Mohrig (1998): 363 [as Cratyna (Cratyna)]; - Menzel \& Mohrig (2000): 347, figs 215-218 [as Hyperlasion] (not Menzel et al. (1997): 145; misidentification, = Hyperlasion wasmanni Schmitz, 1918).

Material examined from the archipelago:

NIGHTINGALE ISLAND: 2nd Pond [central of all

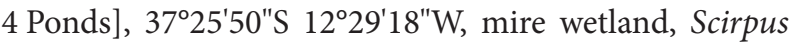
sedges, mosses and Blechnum palmiforme ferns, Malaise trap (site 9, sample N86), 1 o , 26-28.iii.2005, leg. HäNEL. West Landing, $37^{\circ} 24^{\prime} 96^{\prime \prime} \mathrm{S} 12^{\circ} 28^{\prime} 68^{\prime \prime} \mathrm{W}$, coastal boulder platform, fur seals and tussock clumps, Malaise trap (site 5, sample N44), 4 o $^{\top} o^{\top} 22$ 우 우, 31.iii.2005, leg. HäNEL. West Road, $37^{\circ} 25^{\prime} 02^{\prime \prime} \mathrm{S} 12^{\circ} 28^{\prime} 66^{\prime \prime} \mathrm{W}$, path inland from landing, tussock grassland some Scirpus sp. and alien species in path, Malaise trap (site 7, sample N46), 1 , 28-29.iii.2005, leg. HäNEL. TRISTAN DA CUNHA ISLAND: Between Plantation and Council Gulches, 37 $07^{\prime} 43^{\prime \prime S} 12^{\circ} 29^{\prime} 24^{\prime \prime} W$, $1267 \mathrm{ft}$. a.s.l., on path below the 'Rim' [escarpment], open bush (Phylica sp., ferns, heath and grasses), Malaise trap (site 4, sample T45), 3 o $^{\top}$, 10-14.ii.2005, leg. HäNEL. Sandy Point, $37^{\circ} 11^{\prime} 47^{\prime \prime} S 12^{\circ} 22^{\prime} 61^{\prime \prime} \mathrm{W}, 102 \mathrm{ft}$. a.s.l., woodland shrub, behind the hut, Malaise trap (site 9, sample T47), 4 ㅇ ㅇ, 21.ii.2005, leg. HäNEL. Up Molly Gulch, on

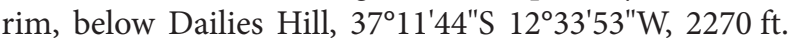
a.s.l., grassland mix, Malaise trap (site 7, sample T49), 1 o , 15-21.ii.2005, leg. HäNEL.

\section{Other material studied:}

Lectotype, o [des. Menzel in Menzel \& Mohrig (2000): 347 and 761]. PORTUGAL: Azores, San Jorge, Lagoa do Calheta, 20.vi.1938, leg. Frey (MZH). 
Paralectotypes, 5 우 ㅇ. PORTUGAL: Azores, San Miguel, Furnas, forest, 23.vii-1.viii.1938, 2 ㅇ ㅇ, leg. Frey (MZH); Azores, San Jorge, Ribeira do Salto, 18-23.vi.1938, 1 우 leg. Frey (MZH); Azores, San Jorge, Lagoa do Calheta, 20.vi.1938, 2 우 우, leg. Frey (MZH).

\section{Distribution:}

The species was previously only known from the Azores (Pico, San Jorge and San Miguel Islands). Accordingly, its status was regarded as a Macaronesian endemic (BoRGES et al. 2005). A total of 36 specimens were collected on
Tristan da Cunha and Nightingale Islands. New to Tristan da Cunha archipelago.

\section{Description:}

Male: Body length: ca $1.8 \mathrm{~mm}$. Head: brown, roundish; eyebridge 2 facets wide, narrowed towards the middle into 1 facet, medially without facets. Antennae dark brown and short; 4th flagellomere 2.1-2.2 times as long as wide (Fig. 16); necks short, pale and well differentiated; basal part 1.7-1.8 times as long as wide, with long, coarse setae and very long sensillae; antennal setae

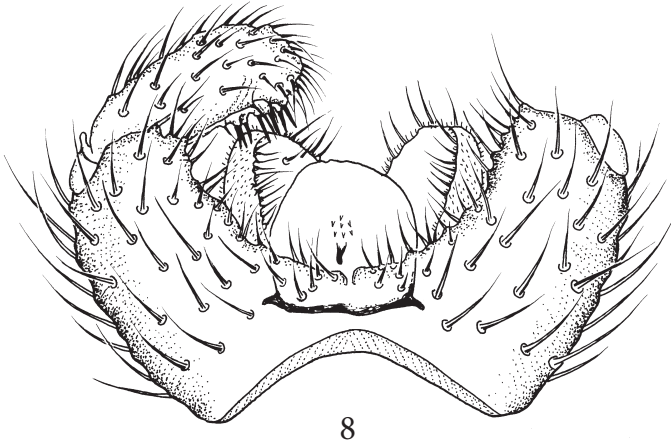

8
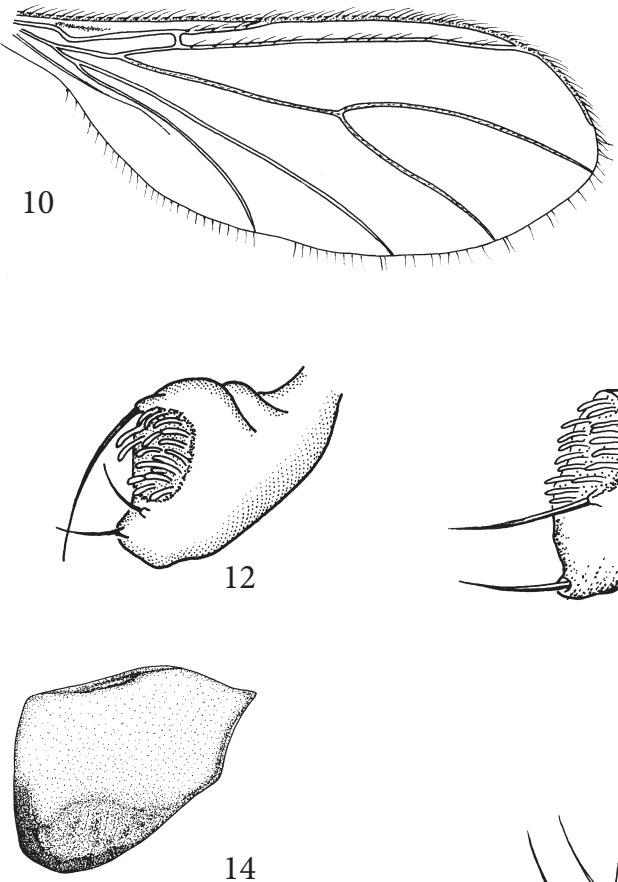

14
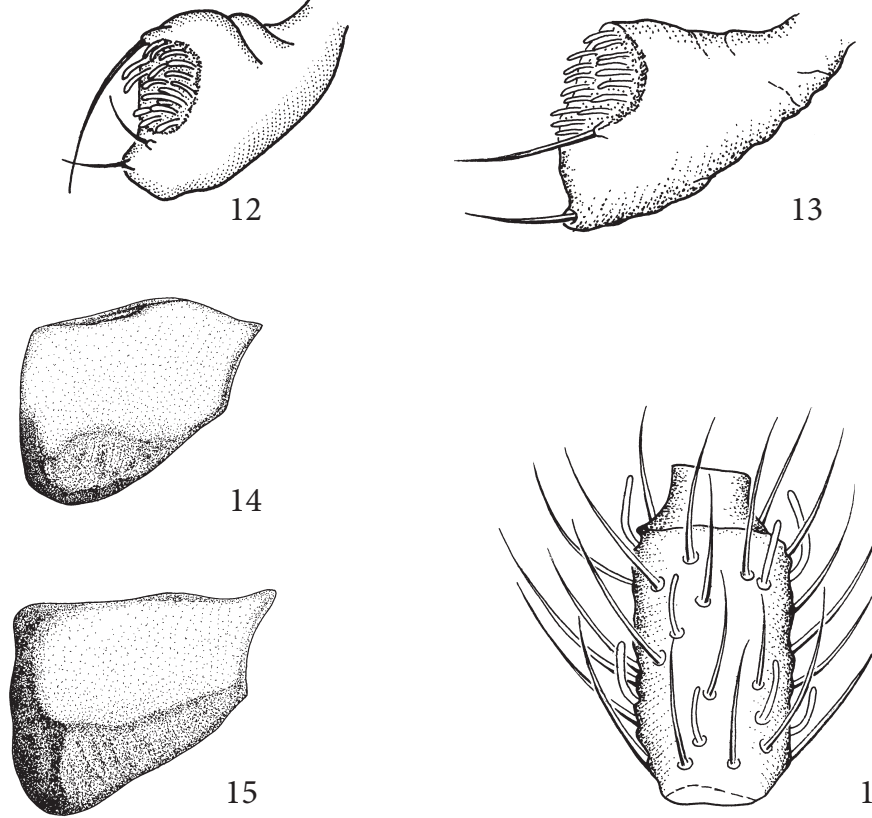

13
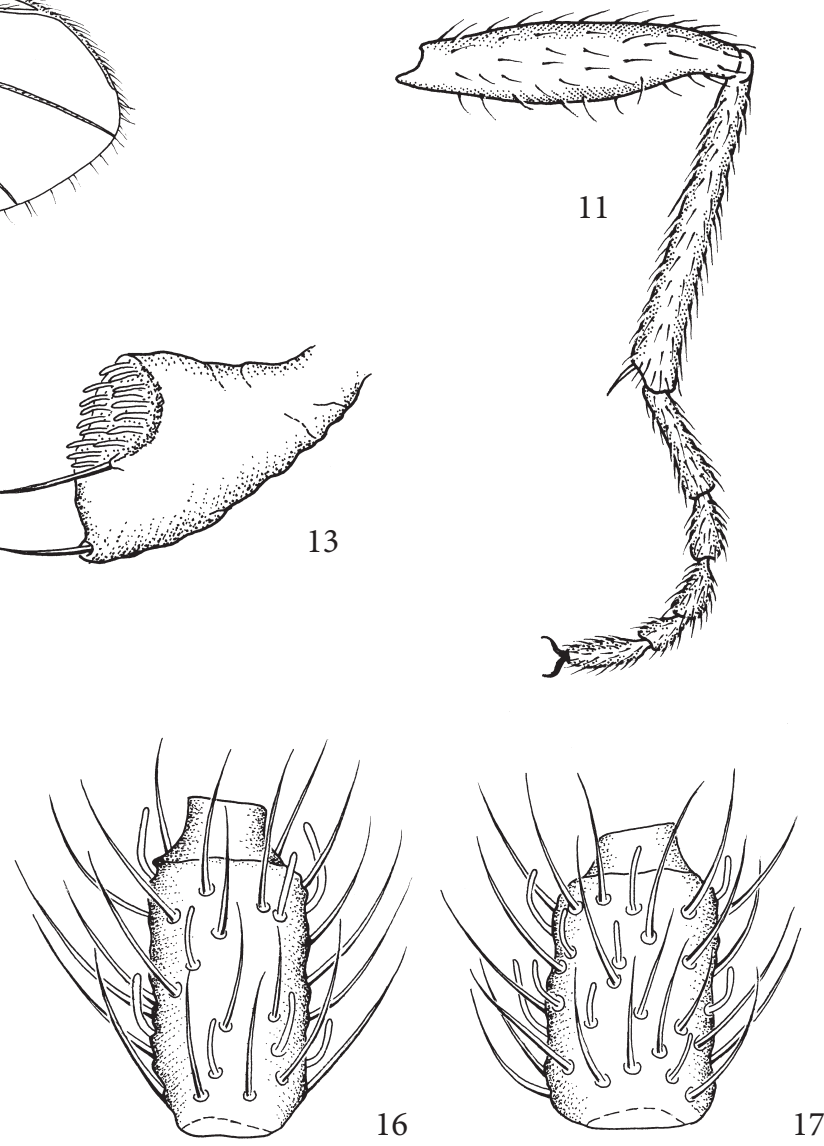

Figs 8-17: Hyperlasion viridiventris (Frey), male and female: - Fig. 8: Hypopygium in ventral view, male; - Fig. 9: Right gonostyle in ventral view, male; - Fig. 10: Wing in lateral view, male; - Fig. 11: Fore leg in lateral view, female; - Fig. 12: Maxillary palp in lateral view, male; - Fig. 13: Maxillary palp in lateral view, female; - Fig. 14: Katepisternum in lateral view, male; - Fig. 15: Katepisternum in lateral view, female; - Fig. 16: 4th flagellomere in lateral view, male; - Fig. 17: 4th flagellomere in lateral view, female. 
slightly longer than segment width. Maxillary palpi yellowish, with one club-like segment (Fig. 12); palpal segment with 2-3 bristles (one long, distinctly curved outer bristle above sensory pit; 1-2 shorter bristles on apex of maxillary palp); sensory pit large, deep and on apex of maxillary palp; sensilla long. Thorax: dark brown. Anterior pronotum with 4-5 setae. Prothoracal episternum short, with 3-5 setae. Postpronotum bare. Katepisternum (Fig. 14) short, low and distinctly emarginated, with cranial hollow. Mesonotum with sparse, short setae and 2-4 longer lateral bristles; scutum short, with rather short and thick laterals, thick and curved dorsocentrals in two indistinct rows, acrocentrals in anterior part only, short and curved. Scutellum distinct with 2 strong marginal bristles and some shorter setae. Legs and coxae short, strong and pale brown; coxae with strong and long setae; legs distinctly compact with short tarsi; fore femur thickened; tibiae short, shorter than tarsi, thickened towards apex; all tibiae without spines among the setae; apex of fore tibia with sparse prolateral patch of setae subapically; tibial spurs $1+2+2$, shorter than diameter of corresponding tibiae, tibial spurs short and pin-like, one spur on mid and hind legs shorter (slightly unequal in length, sometimes both spurs reduced). Claws narrow and straight, without teeth. Wing (Fig. 10) light brown with reduced, wedge shaped base (wing length $1.3 \mathrm{~mm}$, width/length $0.45)$; C with sparse setosity; posterior veins weak and as the wing membrane without macrotrichia; stem of $\mathrm{M}$ longer than $\mathrm{M}$-fork; fork of $\mathrm{M}$ short, triangular and very wide; $\mathrm{x}=\mathrm{y}$, both bare; CuA-stem short, about $1 / 3$ to $1 / 2 \mathrm{x} ; \mathrm{R}_{1}=0.75-0.85 \mathrm{R} ; \mathrm{R}-\mathrm{R}_{1}$ short, merging with $\mathrm{C}$ well before base of M-fork; $\mathrm{c}=0.65-0.80 \mathrm{w}$. Halteres short, strong and brown with short stalk. Abdomen: slightly paler than thorax; body setae sparse, short, fine and dark. Hypopygium (Fig. 8) about as high as wide, pale brown as abdomen; gonocoxites short; intercoxal area unmodified; ventral base widely rounded; inner margin with short, relatively dense setae. Gonostylus (Fig. 9) longish oval, about 2.2 times as long as wide (slightly shorter than gonocoxite); apex widely rounded, with short and strong bristles (no apical tooth); innerside with 7 hyaline megasetae [spines] in upper half arranged in 2 groups (4 subapical and 3 very closely adjacent megasetae in middle). Tegmen higher than wide, unsclerotized and apically roundish; area of teeth very small and round, with fine teeth. Aedeagus very short.

Female: Similar to male but slightly larger. Body length: $2.5 \mathrm{~mm}$. Head: Ocelli present. Eyebridge complete, 2 facets wide. Maxillary palpi with one segment (Fig. 13), with 2-4 bristles (one distinctly longer). Antennae with 14 flagellomeres; basal segments of antennae dark; pedicel enlarged and distinctly attenuated; 4th flagellomere 1.7-2.2 times as long as wide (Fig. 17); necks short and well differentiated; basal part 1.25-1.5 times as long as wide, with coarse, long, erect setae and very long sensillae; setae about as long as segment width. Thorax: Anterior pronotum with 4-5 setae. Prothoracal episternum with 7-8 setae. Katepisternum (Fig. 15) larger and longer than in males, wedge shaped with cranial hollow. Legs slightly thicker than in male, forelegs strong, with swollen femur (Fig. 11); tibial spurs short, one spur on mid and hind legs distinctly shorter (more strongly reduced than in males). Wings distinctly narrower than in males (wing length 1.4-1.6 mm, width/length $0.40-$ 0.45 ); $\mathrm{R}_{1}$ shorter, $=0.5-0.8 \mathrm{R} ; \mathrm{c}=0.85 \mathrm{w}$; necks of halteres slightly shorter. Abdomen: long and narrow, with fine short setae, with greenish tint. All other characteristics as in males.

\section{Discussion:}

Hyperlasion viridiventris (FREY) was described from eight specimens from the Azores, of which one male (lectotype; hypopygium missing) and five females (paralectotypes) are left in the collection of MZH. The new specimens from Tristan da Cunha are in general paler than Frey (1945) indicated in the original description but this may be because the new specimens were kept in alcohol. The published record from the Canary Isle La Gomera in Menzel et al. (1997) is a misidentification [not Cratyna viridiventris (FREY); = Hyperlasion wasmanni Schmitz]. Consequently, to date H. viridiventris is only known from the three Azores Islands and the Tristan da Cunha archipelago. Frey (1945) wrote that there were some densely placed, short bristles inside of apex of the gonostylus. With a higher magnification however, 7 pale, hyaline megasetae can be seen in the upper half of the inner side of the gonostylus (Fig. 9). Hyperlasion viridiventris is similar to the Palaearctic H. wasmanni Schmitz, 1918 [redescription in Menzel \& Mohrig (2000): 346] and H. aliens Mohrig, 2004 from Papua New Guinea and Seychelles Islands [redescription in Menzel \& SMith (2009): 38]. Hyperlasion viridiventris and $H$. aliens both have relatively narrow gonostyles and a widely rounded tegmen apex. In contrast to $H$. viridiventris however, $H$. aliens has shorter flagellomeres with no sensillae on basal parts, a shorter tegmen, the inner side of the gonocoxites have sparse setae and there are only 4 hyaline megasetae on the inner side of the gonostyles. Hyperlasion wasmanni also has 7 megasetae on the inner side of the gonostyles, similar to $H$. viridiventris, but they are arranged differently. The species differ in that $H$. viridiventris has a less narrow hypopygium, the gonostyles are wider with the macrosetae more dorsally situated and the apex of gonostylus has longer setae. Furthermore, the tegmen of $H$. viridiventris is widely rounded, not higher than wide while the tegmen of $H$. wasmanni has a lateral constriction and flattened apex. $H$. viridiventris has a very distinct and unique extremely swollen (almost triangular) basal segment of the maxillary palp, and in the males the long outer bristles are typically above the sensory pit. With both of these characteristics it is possible to distinguish $H$. viridiventris (FREY) from $H$. wasmanni SCHMITZ and $H$. aliens MOHRIG. 
Lycoriella (Lycoriella) ingenua (Dufour, 1839)

(Figs 18, 19)

\section{Synonyms:}

= Molobrus mali FITCH, 1856; = Sciara solani WINNERTZ, 1871; = Sciara pauciseta FeLt, 1897; = Sciara ramicola KIEFFER, 1919; = Sciara caesar JOHANNSEN, 1929; = Niadina jauva RAPP, 1946; = Bradysia (Chaetosciara) mycorum FreY, 1948; = Psilosciara flammulinae SASAKAWA, 1983 [more synonyms in Menzel \& Mohrig (2000)].

\section{Selected literature:}

- Dufour (1839): 29, plate 1, figs 20-28 [as Sciara]; - Fitch (1856): 484 [as Molobrus mali]; - WinNertZ (1871): 852 [as Sciara solani]; - Felt (1897): 224, plate 6, figs 2, 4, 12 [as Sciara pauciseta]; - KIefFer (1919): 202, fig. 11 [as Sciara ramicola]; - TONNOIR \& EDWARDS (1927): 798, plate 70, figs 178, 179 [as Sciara agraria FeLT, misidentification]; - FREY (1948): 59 and 80, plate 12, fig. 66; - Frey (1954): 2 and 10 [all as Bradysia mycorum]; - Тuомікоsкi (1960): 79 and 84, figs 18e, 20e [as Lycoriella solani]; - Yоsнiмото \& GREssitT (1963): 875 [as Sciara agraria FelT, misidentification]; - HoldGate (1965): 396 [as Bradysia mycorum]; - StefFan (1972): 429, fig. 1a-h [als Lycoriella solani]; - STEFFAN (1974): 47 [as Lycoriella mali]; - SASAKAWA (1983): 321, figs 1C, 1D [as Psilosciara flammulinae]; - FREeman (1983): 31 and 43, figs 1-3, 5-8, 92, 100, 104 [as Lyco- riella solani]; - CLIFT \& LARSSON (1984): 49 [as Lycoriella mali]; - Menzel \& Mohrig (2000): 393, figs 43, 89 [as Lycoriella ingenua]; - GASTON et al. (2003): 1096; - JoNES et al. (2003): 241 and 247, fig. 28a [all as Lycoriella sp. A]; - Greenslade \& Clift (2004): 81 [as Lycoriella ingenua and Sciara agraria Felt, misidentification]; - MenzeL et al. (2006): 111; - MoHRIg et al. (2013): 211 [all as Lycoriella ingenua].

Material from the archipelago:

Only known from the literature (Frey 1954, GASTON et al. 2003, Jones et al. 2003).

\section{Distribution:}

Recorded from Gough, Inaccessible and Tristan da Cunha Islands (Frey 1954, Jones et al. 2003). Worldwide distributed. Known from Canada (e.g. Ontario), United States (e.g. California, Illinois, Pennsylvania, Hawaiian Islands: Kauai), Japan, Korea, Australia, Crozet Islands [France], Russia (Asian territory: Far East, Amur, Tuva, Altay), Mongolia, United Arab Emirates, Algeria, Azores [Portugal] and Europe (Austria, Belgium, Bulgaria, Czech Republic, Denmark, Finland, France, Germany, Great Britain, Greece, Iceland, Ireland, Italy, the Netherlands, Norway, Poland, Romania, Russia [European territory], Slovakia, Spain, Sweden, Switzerland, Turkey [European territory]).
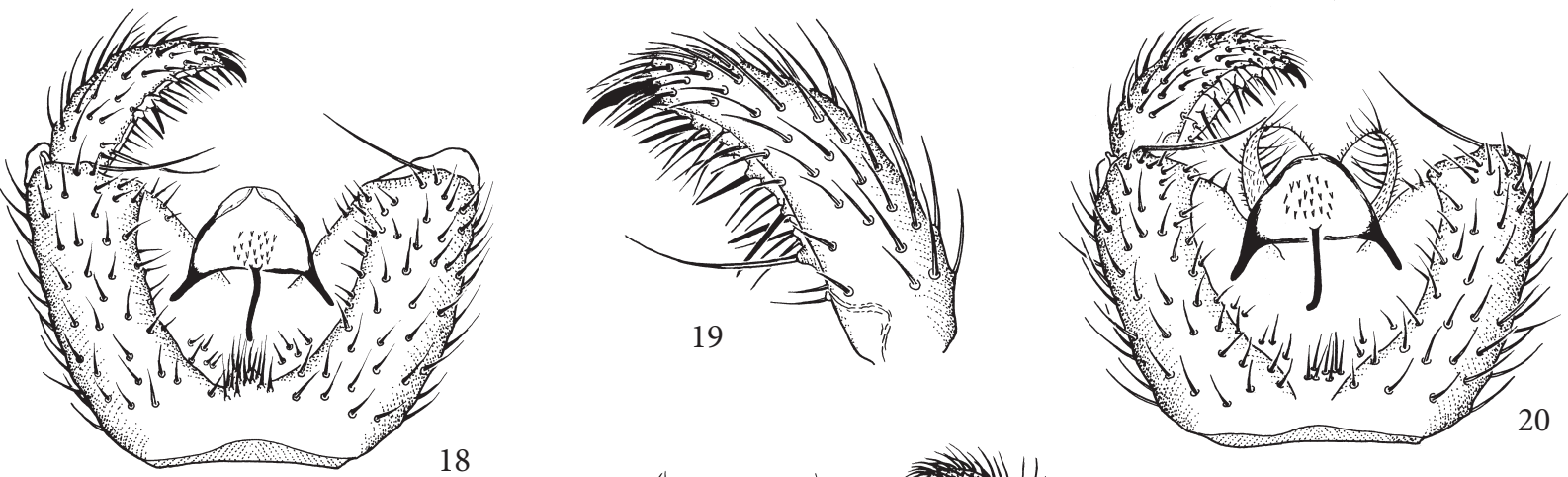

is

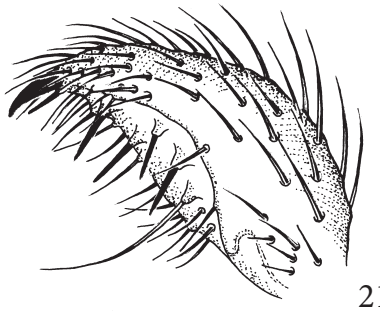

21
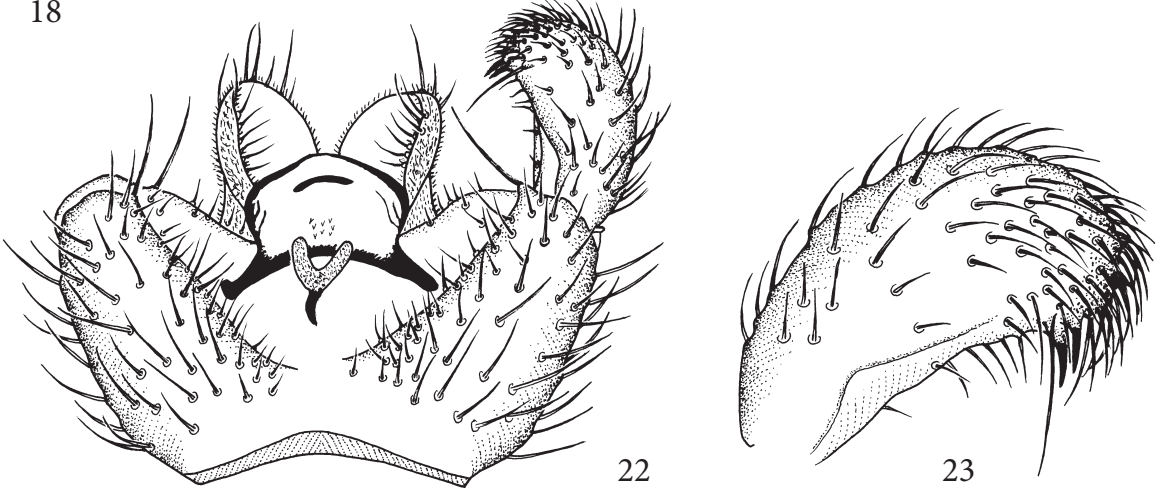

Figs 18-23: Lycoriella ingenua (Dufour), male (Figs 18, 19): - Fig. 18: Hypopygium in ventral view; - Fig. 19: Right gonostyle in ventral view. Lycoriella sativae (Johannsen), male (Figs 20, 21): - Fig. 20: Hypopygium in ventral view; - Fig. 21: Right gonostyle in ventral view. Pseudolycoriella setigera (HARDY), male (Figs 22, 23): - Fig. 22: Hypopygium in ventral view; - Fig. 23: Left gonostyle in ventral view. 
Description: See Menzel \& Mohrig (2000): 393, figs $43,89$.

\section{Discussion:}

Like Lycoriella sativae (JoHANnsen) [= L. castanescens], Lycoriella ingenua is a ubiquitous species associated with fungi. As such it is well known as a pest in cultures of fungi, but it is less frequent than L. sativae in natural ecosystems. It was probably introduced with fungi cultures throughout the world and has formerly been recorded from a couple of other islands. For more detailed information about habitats see Menzel et al. (2006).

\section{Lycoriella (Lycoriella) sativae (JoHANNSEN, 1912)} (Figs 20, 21)

\section{Synonyms:}

= Sciara trifolii Pettey, 1918; = Sciara similans JohanNSEN, 1925; = Neosciara castanescens LENGERSDORF, 1940; = Sciara (Neosciara) brevipetiolata SHAW, 1941; = Sciara (Neosciara) kaiseri SHAw, 1941; = Bradysia (Chaetosciara) difficilis Frey, 1948; = Bradysia (Chaetosciara) fucorum Frey, 1948; = Bradysia (Chaetosciara) paucisetulosa FreY, 1948; = Lycoriella (Lycoriella) rufotincta TuOMIKOSKI, 1959; = Lycoriella agarici LoudoN, 1978.

\section{Selected literature:}

- Lengersdorf (1940): 28, fig. 11 [as Neosciara]; - Frey (1948): 64 and 82 [as Bradysia difficilis]; - FreY (1948): 60 and 80, plate 12, fig. 68 [as Bradysia fucorum]; - FreY (1948): 63 and 82, plate 15, fig. 86 [as Bradysia paucisetulosa]; - Tuомікоsкi (1959): 172, figs 1d, 2b, $2 \mathrm{~h}$ [as Lycoriella rufotincta]; - Tuомікоокі (1960): 82 and 88 , figs $18 \mathrm{c}$, 20c [as Lycoriella fucorum]; - Tuомікомкі (1960): 82 and 88, figs 17g, 18d, 20d; - FreEMAN (1983): 31, figs 93, 102; - Clift \& Larsson (1984): 49 [all as Lycoriella auripila (WINNERTZ), misidentification]; - LoudON (1978): 163, figs 1-8 [as Lycoriella agarici]; - GASTON et al. (2003): 1096; - Jones et al. (2003): 241 and 247, fig. 30b [all as Lycoriella sp. B]; - Menzel \& Mohrig (2000): 386, figs 56, 71b, 353 355; - Greenslade \& Clift (2004): 82; - Menzel et al. (2006): 108 [all as Lycoriella castanescens]; - MoHrig et al. (2013): 216, fig. 39a-d [as Lycoriella sativae].

\section{Material examined from the archipelago:}

TRISTAN DA CUNHA ISLAND: West of Edinburgh settlement, $37^{\circ} 09^{\prime} 06^{\prime \prime S} 12^{\circ} 34^{\prime} 26^{\prime \prime} \mathrm{W}, 127 \mathrm{ft}$. a.s.l., potato patches, cultivated cropland, Malaise trap (site 2, sample T48), $1 \sigma^{\star}, 7-12 . i i .2005$, leg. Hänel. For more records see Gaston et al. (2003) and Jones et al. (2003).

\section{Distribution:}

A common Holarctic species. Known from United States (e.g. Arizona, Idaho, Illinois, Kansas, New York, Oklahoma, Pennsylvania), Australia, China (Taiwan),
Japan, Mongolia, Russia (Asian territory: Far East, Altay), Afghanistan, Turkmenistan, Turkey (Asian territory), Iran, Egypt, Morocco, Canary and Madeira Islands [Spain], Azores [Portugal] and Europe (Austria, Bulgaria, Czech Republic, Denmark, Estonia, Finland, France, Germany, Great Britain, Greece, Iceland, Ireland, Italy, the Netherlands, Norway, Poland, Romania, Russia [European territory], Slovakia, Spain [Iberian Peninsula, Balearic Islands], Sweden, Switzerland). Recorded by Jones et al. (2003) from Gough as Lycoriella sp. B. New to Tristan da Cunha Island.

Description: See Menzel \& Mohrig (2000): 386, figs 56, 71b, 353-355.

\section{Discussion:}

Larvae are found in plant material in the soil and are involved in decomposition. They feed on fungi and in this connection have been regarded as a pest to mushroom growers (e.g. Tibbles et al. 2005). Due to this probable relation with fungal hyphae Lycoriella sativae (JOHANNSEN) [= castanescens (LENGERSDORF)] is common in nearly every kind of ecosystem throughout the Holarctic Region and most probably beyond. It is especially dominant in disturbed ecosystems like cultivated fields and temporarily flooded areas. For more detailed information about habitats see Menzel et al. (2006).

\section{Pseudolycoriella setigera (HARDY, 1960)}

(Figs 22, 23)

\section{Literature:}

- Hardy (1960): 234, fig. 80a-c [as Spathobdella]; - Steffan (1973a): 356; - Leblanc et al. (2009): 1452 and 1455 [all as Bradysia]; - Menzel \& Heller (2007): 223; - Menzel \& SMith (2009): 21 and 41, figs 1.45-1.47; - KöHLer \& Menzel (2013): 69 [all as Pseudolycoriella].

\section{Material examined from the archipelago:}

NIGHTINGALE ISLAND: East Landing area below shacks, coastal boulders with penguin colony and tussock, $37^{\circ} 25^{\prime} 09^{\prime \prime S} 12^{\circ} 28^{\prime} 44^{\prime \prime} \mathrm{W}$, Malaise trap (site 1, sample N43), 2 o $^{\top}$, 1.iv.2005, leg. HäNel. 3rd Pond [closest to top of path], $37^{\circ} 25^{\prime} 53^{\prime \prime} \mathrm{S} 12^{\circ} 29^{\prime} 10^{\prime \prime} \mathrm{W}$, mire wetland with Scirpus sedges, fernbush and mosses, Malaise trap (site 10, sample N79), $1 \sigma^{\star}$, 26.iii.2005, leg. HäNEL. TRISTAN DA CUNHA ISLAND: Between Plantation and Council Gulches, $37^{\circ} 07^{\prime} 43^{\prime \prime S} 12^{\circ} 29^{\prime} 24^{\prime \prime} \mathrm{W}, 1267 \mathrm{ft}$. a.s.l., on path below the 'Rim' [escarpment], open bush (Phylica sp., ferns, heath and grasses), Malaise trap (site 4, sample T45), $10^{\text {T}}, 10-14$. ii.2005, leg. Hänel. Cave Point, $37^{\circ} 16^{\prime} 77^{\prime \prime} \mathrm{S} 12^{\circ} 32^{\prime} 54^{\prime \prime} \mathrm{W}, 71 \mathrm{ft}$. a.s.l., in front of hut, grassland and feral cattle, Malaise trap (site 18, sample T46), 7 ठ઼ $^{\star}, 27-28 . i i .2005$, leg. HäNEL. 


\section{Distribution:}

Only known from Hawaiian Islands (Hawaii, Maui), the Seychelles (Silhouette) and New Caledonia. New to Tristan da Cunha archipelago (Nightingale Island, Tristan da Cunha Island).

Description: See Menzel \& SMith (2009): 41, figs 1.451.47.

\section{Discussion:}

Although Pseudolycoriella setigera has currently been found only on three remote island localities, we suppose, that it is a widespread species. It only appears to be rare, because it does not occur in the Palearctic but possibly in the poorly studied Afrotropical Region. The occurrence on four different archipelagoes leads to the assumption, that it was also introduced by man.

\section{Discussion}

All the species of Black Fungus Gnats that have to date been found at the Tristan archipelago are considered to be alien introductions to the islands. The cosmopolitan Cosmosciara perniciosa (EDWARDS) and Lycoriella ingenua (Dufour) [in Frey (1954) as Bradysia mycorum Frey] that were first found during 1937-38, could well have arrived during the period when the first settlers established themselves on Tristan da Cunha, as livelihoods of both islanders and sailing ships were largely depending on trading and Tristan was the only inhabited island in a long haul for voyagers heading south from Europe. The abundant presence of the two Lycoriella species found in the lowlands at Gough throughout the years 1999-2001 points strongly to them also being alien imports that must have found suitable resources to proliferate, for their large numbers could hardly have been overlooked by the earlier survey of 1955-56.

With these records providing a benchmark for Sciaridae presence within the archipelago, the finding of three additional species in 2005 points to their having been introduced since the last survey of the northern Islands in 1937-38. The occurrence of Hyperlasion viridiventris and Pseudolycoriella setigera at both Tristan and Nightingale was prominent beyond any of the other species. It is curious that Cosmosciara perniciosa, the most widespread sciarid, was not amongst the 2005 collection, although the brevity of the project did not allow coverage of all the habitats, or for material to be adequately curated so that many of the specimens were in too poor a condition to identify beyond family level. However, the much more extensive two-year survey at Gough during 1999-2000 did not find any of these three species on the Island. This strongly points to their introduction into the northern Islands having been mediated by unnatural bridges, such as vessels coming from areas where the species are known to occur. Since the survival and transfer over long distance of these tiny midges is most likely to have been facilitated through vegetable matter, it further points to the import of uncontrolled goods into the territory. All supplies to the Gough World Heritage Site are strictly regulated, to the point that all unprocessed fresh goods have been disallowed since 2000 and visits are restricted principally to staff of the South African weather station and occasionally researchers and other permitted visitors. At Tristan on the other hand, goods continue to be imported with

Tab. 1: Overview of sciarid species recorded from the Tristan da Cunha archipelago. Abbreviation: ${ }^{*}=$ New record for the archipelago.

\begin{tabular}{|c|c|c|c|c|c|}
\hline \multirow[t]{2}{*}{ SPECIES } & \multirow{2}{*}{$\begin{array}{l}\text { LITERATURE } \\
\text { (Records) }\end{array}$} & \multicolumn{4}{|c|}{ ISLANDS } \\
\hline & & Gough & Inacces. & N'gale & Tristan \\
\hline $\begin{array}{l}\text { Bradysia forficulata (BEZzI) } \\
\text { [also as Bradysia nocturna } \\
\text { TuOMIKosKI and Bradysia sp. 1] }\end{array}$ & $\begin{array}{l}\text { FREEMAN (1962) } \\
\text { HoLDGATE (1965) [in part] } \\
\text { GASTON et al. (2003) } \\
\text { JoNEs et al. (2003) }\end{array}$ & $\mathrm{X}$ & & & \\
\hline Bradysia sp. 2 & $\begin{array}{l}\text { FreEman (1962) } \\
\text { Holdate (1965) [in part] }\end{array}$ & $\mathrm{X}$ & & & \\
\hline Bradysia tilicola (LoEw) ${ }^{*}$ & present paper & & & & $\mathrm{X}$ \\
\hline Cosmosciara perniciosa (EDWARDs) & FrEY (1954) & & $\mathrm{X}$ & $\mathrm{X}$ & $\mathrm{X}$ \\
\hline Hyperlasion viridiventris (FREY)* & present paper & & & $\mathrm{X}$ & $\mathrm{X}$ \\
\hline $\begin{array}{l}\text { Lycoriella ingenua (DUFOUR) } \\
\text { [also as Bradysia mycorum FREY } \\
\text { and Lycoriella sp. A] }\end{array}$ & $\begin{array}{l}\text { Frey (1954) } \\
\text { GASTON et al. (2003) } \\
\text { Jones et al. (2003) }\end{array}$ & $\mathrm{X}$ & $\mathrm{X}$ & & $\mathrm{X}$ \\
\hline $\begin{array}{l}\text { Lycoriella sativae (JOHANNSEN) } \\
\text { [also as Lycoriella sp. B] }\end{array}$ & $\begin{array}{l}\text { GASTON et al. (2003) } \\
\text { JonEs et al. (2003) }\end{array}$ & $\mathrm{X}$ & & & $\mathrm{X}$ \\
\hline Pseudolycoriella setigera (HARDY) * & present paper & & & $\mathrm{X}$ & $\mathrm{X}$ \\
\hline Total number of species & $\Sigma=8$ & 4 & 2 & 3 & 6 \\
\hline
\end{tabular}


virtually no restrictions or quarantine controls. Tourists are welcome and landings on all three northern Islands are permissible. The abundance of spectacular and rare birds occurring at the Tristan Island is a source of great attraction that has in recent years brought an increasing number of visitors to the islands, including tour groups. The latter arrive mostly on vessels that do not operate with strict hygiene regulations, such as for instance are enforced by the supply ship 'S.A. Agulhas' when moored at a foreign port and transporting goods and passengers to the Tristan Territory. This is particularly problematic where tour operators run a route of island-hopping expeditions and no quarantine measures are in place. Since the occurrence of the two newly recorded sciarids Pseudolycoriella setigera and Hyperlasion viridiventris is otherwise only known from one locality each on the globe, namely Hawaii and the Azores respectively, and Tristan does not conduct trade with these islands, it points strongly to their import having been via a tourism operation of an uncontrolled type. It is also probable, that these two species have a wider distributional range than only the respective archipelagoes and occur also in continental areas like Africa, South America or East Asia, which are only poorly known concerning their sciarid fauna.

Interesting is that Pseudolycoriella setigera and Hyperlasion viridiventris were represented in various habitats and localities on Tristan and Nightingale, including the male form of $H$. viridiventris which had hitherto been poorly known. Clearly the Islands provide favourable conditions for them. Little to no information exists about the biology and habits of the species, and not much can at this stage be deduced from the 2005 findings alone, as no quantifiable type of collecting methods were employed nor could a comprehensive survey of all habitats be made. It is therefore somewhat curious that on Tristan, the male of Hyperlasion viridiventris was only found at sites higher than $1260 \mathrm{ft}$. a.s.l., despite the fact that collecting efforts were minimal in elevated areas compared to the more extensive ones carried out in the lowlands. However, on Nightingale the males were found at both the high level sites (ca. $660 \mathrm{ft}$. a.s.l.) and at sea level.

Only one of the mentioned species was possibly not introduced by human activities, namely Bradysia forficulata. This was recorded from Gough Island alone, the most isolated island of the archipelago. Adult Sciaridae are transported by atmospheric drift as aeroplankton over distances of more than $1,000 \mathrm{~km}$ (HARrell \& Yoshiмото 1964), so it is possible that Bradysia forficulata may have reached Gough Island in that way. Another indication for this hypothesis is the existence of Bradysia watsoni Colless, 1962 from Macquarie Island in the South Pacific (Colless 1962). We have not studied the type specimen, but regarding the description it is not impossible, that it is identical to B. forficulata. There are currently no endemic species of Sciaridae known from Tristan da Cunha and it is questionable, if sciarid species existed there at all in earlier times before human influence. Endemism is still not proven for Sciaridae, because the distribution of most species is known only fragmentarily and because aerial drift is a common phenomenon in the family. The Tristan da Cunha archipelago is one of the most isolated on earth and there have not been any land bridges to other land masses. That is why there are not even local faunistic elements of Sciaridae, like for example on Campbell Island, with a clear predominance of species from New Zealand (HARrison 1955).

\section{Acknowledgements}

We would like to thank CHristine Hänel (Stellenbosch, South Africa) for collecting of Black Fungus Gnats, letting us study the sciarids from Tristan da Cunha Islands, for information and literature about the sample sites, description of localities and drawing the maps from Tristan and Nightingale that we have used. Additional thanks go to Bianka Katnig (Hohenfinow, Germany) for her technical help with the figures of sciarids, and to KaI Heller (Ellerau, Germany) for his willing help, his very active cooperation, for a lot of scientific discussions, information about the distribution of recorded species, and reviewing former manuscript versions.

We thank the Tristan authorities and James Glass (Agriculture \& Natural Resources Department, Tristan da Cunha) for the opportunity to examine the sciarid specimens, and Ashley Kirk-Spriggs (Albany Museum, Grahamstown, South Africa) for sorting the Diptera collection to family level. Funding for the brief 2005 invertebrate project was made available through a small surplus from the larger program 'Empowering the people of Tristan da Cunha, which was financially backed by the UK Government's Darwin Initiative and implemented by the Royal Society for the Protection of Birds, the UK Partner of BirdLife International \& the Tristan Island Government (C. HäNEL).

\section{References}

Borges, P. A. V.; Vieira, V.; Dinis, F.; Jarrora, S.; Aguiar, C.; Amaral, J.; Aarvik, L.; Ashmole, P.; Ashmole, M.; Amorim, I. R.; André, G.; Argente, M. C.; Arraiol, A.; Cabrera, A.; Diaz, S.; Enghoff, H.; Gaspar, C.; Mendonça, E. P.; Gisbert, H. M.; $\quad$ Gonçalves, P.; $\quad$ Lopes, D. H.; Melo, C.; Mota, J. A.; Oliveira, O.; Oromí, P.; Pereira, F.; Pombo, D. T.; Quartau, J. A.; Ribeiro, S. P.; Rodrigues, A. C.; Santos, A. M. C.; Serrano, A. R. M.; Simões, A. M.; Soares, A. O.; Sousa, A. B.; Vieira, L.; Vitorino, A. \& Wunderlich, J. 2005: 4.4 Lista dos Artrópodes [List of arthropods (Arthropoda)]. - Pp. 163-221. - In: Borges, P. A. V.; Cunha, R. \& Gabriel, R.; Martins, A. M. F.; Silva, L. \& Vieira, V. (eds): 
Listagem da Fauna (Mollusca e Arthropoda) e Flora (Bryophyta, Pteridophyta e Spermatophyta) Terrestres dos Açores [A List of Terrestrial Fauna (Mollusca and Arthropoda) and Flora (Bryophyta, Pteridophyta and Spermatophyta) from the Azores]: 318 pp.; Horta, Angra do Heroísmo \& Ponta Delgada: Direcção Regional de Ambiente \& Universidade dos Açores.

Clift, A. D. \& Larsson, S. F. 1984: The incidence and ecology of Lycoriella mali (FITCH) (Diptera: Sciaridae) in the commercial culture of two species of mushroom in N. S. W. - General and Applied Entomology 16: 49-56.

Colless, D. H. 1962: Insects of Macquarie Island. Diptera: Sciaridae. - Pacific Insects 4 (4): 955-957.

Dufour, L. 1839: Mémoire sur les métamorphoses de plusieurs larves fongivores appartenant à des Diptères. - Annales des Sciences Naturelle (Seconde Série) (Zoologie) 12: 5-60.

EDWARDS, F. W. 1922: A third new British Plastosciara (Diptera, Sciaridae). - The Entomologist's Monthly Magazine 58: 160-161.

Felt, E. P. 1897: Additional notes on Sciara. The fungus gnats. (Ord. Diptera: Fam. Mycetophilidae). - Report on the injurious and other insects of the State of New York for the year 1896. [as 'Report of the State Entomologist'] 12 (1896): 223-228.

Fitch, A. 1856: Report on the noxious, beneficial and other insects of the State of New York [II]. Transactions of the New York State Agricultural Society 15 (1855): 409-559.

Freeman, P. 1962: Diptera Nematocera from Gough Island, South Atlantic. - Proceedings of the Royal Entomological Society of London (Series B) 31 (5-6): 77-80.

Freeman, P. 1983: Sciarid flies. Diptera, Sciaridae. Handbooks for the Identification of British Insects 9 (6): $68 \mathrm{pp}$.

Frey, R. 1936: Die Dipterenfauna der Kanarischen Inseln und ihre Probleme. I. Verzeichnis der Dipteren der Kanarischen Inseln. - Commentationes biologicae 6 (1): 1-237.

Frey, R. 1945: Tiergeographische Studien über die Dipterenfauna der Azoren. I. Verzeichnis der bisher von den Azoren bekannten Dipteren. - Commentationes biologicae 8 (10): 1-114.

FrEY, R. 1948: Entwurf einer neuen Klassifikation der Mückenfamilie Sciaridae (Lycoriidae). II. Die nordeuropäischen Arten. - Notulae Entomologicae 27 (2-4): 33-112.

Frey, R. 1954: Diptera Brachycera und Sciaridae von Tristan da Cunha. - Results of the Norwegian Scientific Expedition to Tristan da Cunha 1937-1938 26: $1-55$

Gaston, K. J.; Jones, A. G.; Hänel, C. \& Chown, S. L. 2003: Rates of species introduction to a remote oceanic island. - Proceedings of the Royal Society of London (Series B) 270: 1091-1098.
Greenslade, P. \& Clift, A. 2004: Review of pest arthropods recorded from commercial mushroom farms in Australia. - Australasian Mycologist 23 (3): 77-93.

HäNEL, C. 2005: Tristan da Cunha Invertebrate Project Report. - Royal Society for Protection of Birds, Sandy, United Kingdom. Internal manuscript: 70 pp. [unpublished].

Hänel, C.; Chown, S. L. \& Gaston, K. J. 2005: Gough Island. A Natural History. 169 pp. + 173 plates; Stellenbosch: Sun Press.

Hänel, C. \& Heyne, H. 2008: Ticks of the Tristan da Cunha Archipelago (Acarina: Ixodidae: Argasidae). Beiträge zur Entomologie 58 (1): 121-134.

Hardy, D. E. 1956: New Hawaiian Sciaridae (Diptera). Proceedings of the Hawaiian Entomological Society 16 (1): 72-90.

Hardy, D. E. 1960: Diptera: Nematocera - Brachycera. - Insects of Hawaii. A Manual of the Insects of the Hawaiian Islands, including an Enumeration of the Species and Notes on their Origin, Distribution, Hosts, Parasites, etc.; University of Hawaii Press, Honolulu 10: 1-268.

Harrell, J. C. \& Yoshimoto, C. M. 1964: Trapping of air-borne insects on ships on the Pacific, part 5. Pacific Insects 6 (2): 274-282.

HARrison, R. A. 1955: Report on Diptera of Auckland and Campbell Islands. - Records of the Dominion Museum 2 (4): 205-231.

Heller, K. \& Weber, D. 2013: Trauermücken (Diptera: Sciaridae) aus Höhlen des Großherzogtums Luxemburg. - Pp. 320-336. - In: Weber, D. (ed.): Die Höhlenfauna Luxemburgs. - Ferrantia 69: 408 pp.; Luxembourg: Musée national d'histoire naturelle du Luxembourg.

Holdgate, M. W. 1965: The biological report of the Royal Society Expedition to Tristan da Cunha, 1962. Part III. The fauna of the Tristan da Cunha Islands. - Philosophical Transactions of the Royal Society of London (Series B) 249: 361-402.

Hutton, F. W. 1902: Additions to the Diptera Fauna of New Zealand. - Transactions of the New Zealand Institute 34 (1901): 179-196.

Johannsen, O. A. 1912: The fungus gnats of North America, Part IV. - Bulletin of the Maine Agricultural Experimental Station 200: 57-146.

Jones, A. G.; Chown, S. L.; Webb, T. J. \& Gaston, K. J. 2003: The free-living pterygote insects of Gough Island, South Atlantic Ocean. - Systematics and Biodiversity 1 (2): 213-273.

Kieffer, J. J. 1919: Microdiptères d'Afrique. - Bulletin de la Société d'Histoire naturelle de l'Afrique du Nord 10 (9): 191-206.

KöHLER, A. \& Menzel, F. 2013: New records of Black Fungus Gnats (Diptera: Sciaridae) from New Caledonia, with the description of two new Bradysia species and an updated checklist. - Zootaxa 3718 (1): 63-72. 
Leblanc, L.; Rubinoff, D. \& Vargas, R. I. 2009: Attraction of Nontarget Species to Fruit Fly (Diptera: Tephritidae) Male Lures and Decaying Fruit Flies in Traps in Hawaii. - Environmental Entomology 38 (5): 1447-1461.

LENGERSDORF, F. 1940: Beitrag zur Kenntnis der Sciariden (Lycoriiden) aus Finnland. - Zoologischer Anzeiger 131 (1-2): 23-29.

LintneR, J. A. 1895: Sciara coprophila n. sp. The Manurefly. (Ord. Diptera: Fam. Mycetophilidae). - Annual Report of the New York State Museum 48 (66) (1894): 391-397.

Loew, H. 1850: Dipterologische Beiträge 4: 40 pp.; Posen: J. J. Heine.

Loudon, B. J. 1978: A new species of Lycoriella FrEY (Diptera: Sciaridae) infesting cultivated mushrooms in New South Wales. - Journal of the Australian Entomological Society 17: 163-166.

Menzel, F. \& Heller, K. 2005: Sechs neue Arten aus den Gattungen Bradysia, Camptochaeta und Corynoptera (Diptera: Sciaridae) nebst einigen Bemerkungen zur Nomenklatur europäischer Trauermücken. - Studia dipterologica 11 (2) (2004): 335-357.

Menzel, F. \& Heller, K. 2007: Bemerkungen zur Nomenklatur der Sciariden (Diptera, Bibionomorpha: Sciaridae). - Studia dipterologica 13 (2) (2006): 209-229.

Menzel, F. \& Mohrig, W. 1998: Beiträge zur Taxonomie und Faunistik der paläarktischen Trauermücken (Diptera, Sciaridae). Teil VI - Neue Ergebnisse aus Typenuntersuchungen und die daraus resultierenden taxonomisch-nomenklatorischen Konsequenzen. Studia dipterologica 5 (2): 351-378.

Menzel, F. \& Mohrig, W. 2000: Revision der paläarktischen Trauermücken (Diptera: Sciaridae). - Studia dipterologica Supplement 6 (1999): 761 pp.

Menzel, F.; Mohrig, W. \& BÁez, M. 1997: Die Trauermücken-Fauna der Kanarischen Inseln, unter Berücksichtigung der von Richard FrEY beschriebenen Arten (Insecta: Diptera, Sciaridae). - Vieraea 25 1996: 133-146.

Menzel, F. \& Smith, J. E. 2009: Family Sciaridae. Pp. 19-45. - In: Gerlach, J. (ed.): The Diptera of the Seychelles islands. - Pensoft Series Faunistica 85: $431 \mathrm{pp}$.

Menzel, F.; Smith, J. E. \& Chandler, P. J. 2006: The sciarid fauna of the British Isles (Diptera: Sciaridae), including descriptions of six new species. - Zoological Journal of the Linnean Society 146 (1): 1-147.

Mohrig, W. \& Menzel, F. 1993: Revision der paläarktischen Arten der Bradysia brunnipes-Gruppe (Diptera, Sciaridae). - Bonner Zoologische Beiträge 44 (3-4): 267-291.

Mohrig, W.; Heller, K.; Hippa, H.; Vilkamaa, P. \& Menzel, F. 2013: Revision of Black Fungus Gnats (Diptera: Sciaridae) of North America. - Studia dipterologica 19 (1-2) (2012): 141-286.
ReEves, W. K. 2000: Invertebrate cavernicoles of the Great Smoky Mountains National Park, USA. Journal of the Elisha Mitchell Scientific Society 116 (4): 334-343.

Reeves, W. K.; Jensen, J. B. \& Ozier, J. C. 2000: New faunal and fungal records from caves in Georgia, USA. - Journal of Cave and Karst Studies 62 (3): 169-179.

Rulik, B.; Röschmann, F. \& Mohrig, W. 1999: New species of sciarid flies (Diptera, Sciaridae) from Greece and Turkey. - Journal of the Entomological Research Society 1 (3): 21-50.

Sasakawa, M. 1983: Two new species of Sciaridae (Diptera). - Kontyû 51 (3): 319-321.

Steffan, W. A. 1966: A generic revision of the family Sciaridae (Diptera) of America North of Mexico. University of California Publications in Entomology 44: 1-77.

Steffan, W. A. 1972: Lycoriella solani (Winnertz) from the Crozet Islands (Diptera: Sciaridae). - Pacific Insects 14 (2): 429-431.

Steffan, W. A. 1973a: Notes on Hawaiian Sciaridae (Diptera) and descriptions of two new species. Pacific Insects 15 (3-4): 353-361.

Steffan, W. A. 1973b: Polymorphism in Plastosciara perniciosa. - Science 182: 1265-1266.

StefFAN, W. A. 1974: Laboratory studies and ecological notes on Hawaiian Sciaridae (Diptera). - Pacific Insects 16 (1): 41-50.

Tibbles, L. L.; Chandler, D.; Mead, A.; Jervis, M. \& BoDDY, L. 2005: Evaluation of the behavioural response of the flies Megaselia halterata and Lycoriella castanescens to different mushroom cultivation materials. - Entomologia Experimentalis et Applicata 116 (2): 73-81.

TonNoir, A. L. \& Edwards, F. W. 1927: New Zealand Fungus Gnats (Diptera, Mycetophilidae). - Transactions and Proceedings of the New Zealand Institute 57: 747-878.

Tuomikoski, R. 1959: Sciariden (Dipt.) aus Afghanistan, gesammelt von Dr. K. Lindberg. - Annales Entomologici Fennici 25 (3): 163-180.

Tuомiкоsкi, R. 1960: Zur Kenntnis der Sciariden (Dipt.) Finnlands. - Annales Zoologici Societatis Zoologicae Botanicae Fennicae 'Vanamo' 21 (4): 1-164.

Winnertz, J. 1867: Beitrag zu einer Monographie der Sciarinen: 187 pp.; Wien: W. Braumüller.

WinnerTz, J. 1871: Vierzehn neue Arten der Gattung Sciara. - Verhandlungen der kaiserlich-königlichen zoologisch-botanischen Gesellschaft in Wien 21: 847-860.

Yoshimoto, C. M. \& GressitT, J. L. 1963: Trapping of air-borne insects in the Pacific-Antarctic area, 2. Pacific Insects 5 (4): 873-883. 